\title{
Wickerhamomyces Yeast Killer Toxins' Medical Applications
}

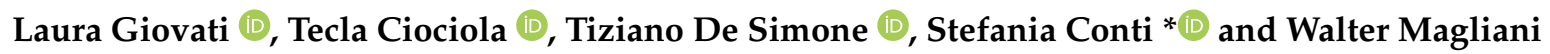 \\ Department of Medicine and Surgery, University of Parma, 43126 Parma, Italy; laura.giovati@unipr.it (L.G.); \\ tecla.ciociola@unipr.it (T.C.); tiziano.desimone@unipr.it (T.D.S.); walter.magliani@unipr.it (W.M.) \\ * Correspondence: stefania.conti@unipr.it
}

check for updates

Citation: Giovati, L.; Ciociola, T.; De Simone, T.; Conti, S.; Magliani, W. Wickerhamomyces Yeast Killer Toxins' Medical Applications. Toxins 2021, 13, 655. https://doi.org/10.3390/ toxins13090655

Received: 10 August 2021

Accepted: 13 September 2021

Published: 15 September 2021

Publisher's Note: MDPI stays neutral with regard to jurisdictional claims in published maps and institutional affiliations.

\begin{abstract}
Possible implications and applications of the yeast killer phenomenon in the fight against infectious diseases are reviewed, with particular reference to some wide-spectrum killer toxins (KTs) produced by Wickerhamomyces anomalus and other related species. A perspective on the applications of these KTs in the medical field is provided considering (1) a direct use of killer strains, in particular in the symbiotic control of arthropod-borne diseases; (2) a direct use of KTs as experimental therapeutic agents; (3) the production, through the idiotypic network, of immunological derivatives of KTs and their use as potential anti-infective therapeutics. Studies on immunological derivatives of KTs in the context of vaccine development are also described.
\end{abstract}

Keywords: killer yeasts; killer toxins; antimicrobial activity; medical applications; Wickerhamomyces anomalus

Key Contribution: Wide-spectrum yeast killer toxins (KTs) produced by Wickerhamomyces anomalus and other related species may have several applications in the medical field. Yeasts producing KT may be used in the symbiotic control of arthropod-borne diseases, while KTs and their immunological derivatives may be exploited for the design of novel anti-infective therapeutics and vaccines.

\section{Introduction}

Competition for space, nutrients and other resources in the environment is a rather common mechanism through which different species of microorganisms can interact with or prevail over others, determining the composition of microbial communities within different ecological niches. The production and excretion of molecules with toxic activity, such as bacteriocins and yeast killer toxins, can be included among the mechanisms by which some microorganisms can harm or kill their competitors, contributing to natural selection.

Bacteriocins are ribosomally synthesized antimicrobial peptides produced from a wide variety of bacteria that inhibit the growth of similar or closely related bacterial strains. Broad-spectrum bacteriocins have also been described. Based on their structure, mode of action, mechanism of biosynthesis and self-immunity, bacteriocins could deserve serious consideration as potential alternatives to traditional antimicrobials for use in agriculture, food storage, veterinary and even human medicine [1-3].

A similar phenomenon of competition is present in yeasts, based on the production of killer toxins (KTs, or mycocins) that are secreted proteins or glycoproteins capable of killing susceptible microorganisms with various mechanisms of action, through interaction with specific superficial receptors. Interestingly, killer yeasts are immune to their own KTs. Since the first description of the "killer phenomenon" in Saccharomyces cerevisiae, by Bevan and Makower in 1963 [4], more than 100 different species of yeasts belonging to more than forty genera, including basidiomycetes and ascomycetes, have been described as killer yeasts, thus attesting to the widespread diffusion of the phenomenon and its ecological relevance [5,6]. Numerous studies over the years have greatly contributed to clarifying the molecular characteristics of various KTs, their physiology and mode of action and the genetic determinants encoding for their production. As relatively simple eukaryotic cells, 
killer yeasts have also represented a valid model to study relevant aspects of eukaryotic cell biology, such as mechanisms of processing and extracellular secretion of proteins. Comprehensive reviews have been published on these subjects to which the reader is referred [5-12].

Although the spectrum of antimicrobial activity of KTs was initially considered limited to susceptible cells belonging to the same species as the producing yeast or to closely related species, it is now known that some KTs may be active against a great variety of eukaryotic and prokaryotic microorganisms. Taxonomically unrelated fungi, bacteria, protozoa and even achlorophyllous saprophytic algae are among the described KT-susceptible strains, including spoilage and pathogenic microorganisms involved in relevant plant, animal and human infections [6]. The mode of action, which still needs to be clarified for many KTs, is variable and includes cell wall or membrane damages as well as arrest of the cell cycle [10].

As natural antimicrobials, KTs and the producing killer yeasts have been exploited for possible applications in food production and preservation as well as in biological control of plant, animal and human pathogens $[5,10,13]$. Some KTs produced by Wickerhamomyces anomalus and other species belonging to the genera Pichia and Williopsis have aroused particular interest for potential applications in the medical field.

\section{Wickerhamomyces anomalus Killer Strains and WaKTs}

In the last two decades, there has been a continuous reclassification of yeasts, including KT-producing strains, into new genera and species. For example, based on nuclear DNA reassociation studies and phylogenetic analysis of gene sequences, species of the genus Hansenula have been reassigned to the genus Pichia and then to the genus Wickerhamomyces [14-17]. Among the species belonging to this genus, W. anomalus has aroused particular interest in microbiology and biotechnology fields, food production and biopreservation, as well as the development of innovative therapeutics, due to its specific characteristics, adaptation properties, frequent detection in natural environments (plants, soil, fruits, animals) and involvement in various fermentation processes [18]. Another key feature of $W$. anomalus is its capability to produce and secrete KTs, characterized by a broad spectrum of activity, comprising relevant plant, animal and human pathogens $[19,20]$. Many KTs exert their optimal activity at acidic $\mathrm{pH}$ and temperatures below $30^{\circ} \mathrm{C}$, which could be a problem for biomedical application [5]. Over the years, various KTs produced by W. anomalus (named WaKTs or, previously, PaKTs and HaKTs) have been described [21-24]. Notably, some killer strains can produce more than one toxin with different characteristics [25]. The most attractive features of some of these chromosomally encoded KTs [26] are the broad spectrum of activity and their mechanism of action, mediated by the interaction with specific cell wall receptors. In most cases, 1,3 or 1,6 $\beta$-glucans are the potential receptors and/or targets of KTs, sometimes characterized by exo- $\beta$-glucanase activity $[21,24,27-29]$.

\section{Killer Toxins' Medical Applications}

Three possible medical applications of $W$. anomalus and related species killer strains or their KTs have been tested and suggested: 1 . direct use of killer yeasts as biological competitors; 2 . direct use of KTs as potential antimicrobial molecules with broad activity; 3. production and use of immunological derivatives of KTs. In the following paragraphs, killer strains and KTs for these applications are described (summarized in Table 1). 
Table 1. Killer strains and KTs for applications in the medical field.

\begin{tabular}{|c|c|c|c|c|c|c|}
\hline Killer Toxin (KT) & KT Producer & $\mathrm{MM}(\mathrm{kDa})^{1}$ & Target & Function & Application & References \\
\hline WaF17.12 & $\begin{array}{l}\text { Wickerhamomyces } \\
\text { anomalus F17.12 }\end{array}$ & 140 & $\begin{array}{l}\text { Plasmodium } \\
\text { berghei }\end{array}$ & $\begin{array}{l}\beta \text {-glucanase } \\
\text { activity }\end{array}$ & Killer yeast & [30-33] \\
\hline Wa96603KT & $\begin{array}{l}\text { W. anomalus } \\
\text { ATCC } 96603\end{array}$ & 220 & $\begin{array}{l}\text { Bacteria, fungi, } \\
\text { protozoa, viruses }\end{array}$ & Various/nd & $\begin{array}{c}\mathrm{KT} \text { and } \\
\text { derivatives }\end{array}$ & [34-40] \\
\hline HM-1 & $\begin{array}{l}\text { W. saturnus var. } \\
\text { mrakii IFO } 0895\end{array}$ & 10.7 & Yeasts & $\begin{array}{c}\text { Inhibition of } \\
\beta-1,3 \text {-glucan } \\
\text { synthase }\end{array}$ & $\begin{array}{c}\mathrm{KT} \text { and } \\
\text { derivatives }\end{array}$ & [41-48] \\
\hline Panomycocin & $\begin{array}{l}\text { W. anomalus } \\
\text { NCYC } 434\end{array}$ & 49 & $\begin{array}{l}\text { Human } \\
\text { dermatophytes, } \\
\text { Candida spp. }\end{array}$ & $\begin{array}{l}\beta \text {-glucanase } \\
\text { activity }\end{array}$ & $\mathrm{KT}$ & {$[21,28,49-52]$} \\
\hline Wa1F1-KT & W. anomalus $1 \mathrm{~F} 1$ & $160-170$ & Candida spp. & $\begin{array}{l}\beta \text {-glucanase } \\
\text { activity }\end{array}$ & $\mathrm{KT}$ & [24] \\
\hline $\begin{array}{l}\text { WA40M1, } \\
\text { WA45M2 and } \\
\text { WA92M3 }\end{array}$ & $\begin{array}{l}\text { W. anomalus } \\
\text { WA40, WA45 } \\
\text { and WA92 }\end{array}$ & nd & $\begin{array}{l}\text { C. albicans, } \\
\text { Acinetobacter } \\
\text { baumannii }\end{array}$ & nd & KT & {$[53,54]$} \\
\hline KT & $\begin{array}{l}\text { W. anomalus } \\
\text { LMA-827 }\end{array}$ & nd & Listeria sp. & Pore formation & KT & [55] \\
\hline KT & $\begin{array}{l}\text { W. anomalus } \\
\text { YF07b }\end{array}$ & 67 & Candida spp. & $\begin{array}{l}\text { Membrane per- } \\
\text { meabilization }\end{array}$ & $\mathrm{KT}$ & [56] \\
\hline Mycocin & $\begin{array}{l}\text { W. anomalus } \\
\text { tp2-15 }\end{array}$ & 45,50 & $\begin{array}{l}\text { Candida } \\
\text { mesorugosa }\end{array}$ & $\begin{array}{l}\beta \text {-glucanase } \\
\text { activity }\end{array}$ & KT & [57] \\
\hline
\end{tabular}

${ }^{1} \mathrm{MM}$, molecular mass (kDa); nd, not determined.

\subsection{Direct Use of Killer Yeasts}

The direct application of some killer yeasts as biocontrol agents against mold and bacteria in the agro-food field has been suggested by many authors [58,59]. In the medical field, a more recent interesting proposal concerns the use of toxin-producing $W$. anomalus strains in the symbiotic control of arthropod-borne diseases [60]. In particular, a W. anomalus killer strain (WaF17.12) has been isolated from the murine malaria vector Anopheles stephensi. WaF17.12 has been reported to secrete a glycoproteic KT of about $140 \mathrm{kDa}$, characterized by a strong anti-plasmodial activity against Plasmodium berghei that causes malaria in rodents [30,31]. This KT inhibited early plasmodial sporogonic stages (ookinetes), causing several morphological and structural alterations, thus severely compromising the parasite survival. Its antimicrobial action has been associated with a $\beta$-glucanase activity, responsible for the hydrolysis of $\beta$-glucans located in the parasite cell membrane. Additional studies confirmed the ability of KT to damage the parasite also in vivo, thus preventing its development in the mosquito midgut and its possible transmission by the biological vector [32,33]. Since symbiotic strains of $W$. anomalus have been isolated in several vector species [61,62], further studies will hopefully clarify whether the produced KTs are also capable of interfering with other arthropod-borne pathogens. These observations suggest the potential benefits of this killer yeast-based approach in preventing the transmission of relevant vector-borne diseases.

\subsection{Direct Use of Killer Toxins}

Although most KTs have a very narrow spectrum of activity, some produced by W. anomalus and Williopsis saturnus var. mrakii (previously known as Hansenula mrakii) have a broader spectrum.

Many years ago, Polonelli et al. first isolated a killer strain (UP25F, now ATCC 96603) of Pichia anomala (now W. anomalus) able to produce a KT (Wa96603KT) characterized by a broad spectrum of activity, including Gram-positive and Gram-negative bacteria, in addition to yeasts and filamentous fungi [34]. Although not yet fully understood, the mechanism of action of Wa96603KT seems to involve $\beta-1,3 \mathrm{D}$-glucans as the potential receptors and/or targets. A possible direct use of Wa96603KT as a therapeutic agent has 
been investigated in different models of experimental infection, such as pneumocystosis in SCID mice, by in vitro attachment tests and in vivo infectivity assays, [35] and superficial Malassezia furfur infection in guinea pigs [63]. Despite the positive results of such experimental approaches, the use of $W a 96603 \mathrm{KT}$ as a systemic therapeutic agent was prevented by the physico-chemical features of the molecule. Therapy by parenteral administration was unfeasible because of Wa96603KT ineffectiveness at the physiological $\mathrm{pH}$ and temperature conditions. Moreover, due to the high molecular weight $(220 \mathrm{kDa})$, Wa96603KT proved to be strongly antigenic. Furthermore, when perfused in a rat small intestine model, Wa96603KT induced secretion and severe acute injury due to ischemic degeneration of villi and sloughing of surface epithelium [64].

Another interesting, wide-spectrum KT (HM-1) has been identified in W. saturnus var. mrakii IFO 0895. This KT, composed of 88 amino acids with five disulfide bridges, proved to inhibit yeast cells in the growing stage without being toxic to mammalian cells $[41,44]$. HM-1 is believed to bind to a receptor in the yeast cell wall, then to a putative receptor on the cell membrane and finally inhibit $\beta$-1,3-glucan synthase with a cytocidal effect in sensitive cells $[42,43]$. Even if HM-1 proved to be highly stable in a wide range of temperature and $\mathrm{pH}$ values (between 2 and 11), its possible direct clinical use was excluded for its antigenicity to the host.

Panomycocin is another wide-spectrum KT, active also against human dermatophytes and Candida spp., which is produced by the W. anomalus killer strain NCYC 434. It is a $49 \mathrm{kDa}$ monomeric glycoprotein with an exo- $\beta$-1,3-glucanase activity, and it is able to kill target cells by disrupting their cell wall. It has exactly the same amino acid sequence as the exo- $\beta-1,3$-glucanase produced by $W$. anomalus strain $K[21,28,49,50]$. In an attempt to minimize the in vivo adverse effects of the molecule and to obtain therapeutic preparations to be envisaged at least for topical use, panomycocin has been encapsulated in a biocompatible, biodegradable and nontoxic lipid mixture similar to the lipid composition of the epidermal stratum corneum. In this formulation, panomycocin displayed a strong in vitro anti-Candida activity. When tested on a commercially available reconstructed human vaginal epithelium model, experimentally infected with Candida albicans and C. glabrata vaginal isolates, the formulation was strongly fungicidal [51]. Further studies were conducted to enhance panomycocin thermal stability at body temperature. By site-directed mutagenesis, a changed toxin has been designed to be stable for potential topical therapeutic purposes in an acidic environment, such as the vagina [52].

Other KTs produced by W. anomalus strains isolated from plants, marine environment, milk, or insect microbiota showed to exert direct antimicrobial activity on different yeast species, including azole-resistant clinical isolates of C. albicans and C. glabrata [24,53,56,57], malaria parasites [32] and pathogenic bacteria, such as Listeria monocytogenes and multidrugresistant strains of Acinetobacter baumannii [54,55].

Overall, the results obtained in the studies on the direct use of KTs as antimicrobial therapeutics leave many questions open, with particular regard to their in vivo activity, stability, toxicity and safety. As outlined before, the reported KTs are usually high molecular weight proteins/glycoproteins, therefore highly antigenic. A possible solution to this issue could be provided by new technological approaches. Analysis of KT sequence and changes in amino acid composition could allow the identification of the molecule's active site to find inside the sequence of KT small peptides still retaining the antimicrobial activity. Selvakumar et al. [65], on the basis of the amino acid sequence, synthesized thirteen overlapping peptides from the primary structure of HM-1. Scanning analysis of these peptides by immunoblotting, surface plasmon resonance and yeast growth inhibition assays identified a peptide, named P6 $\left({ }^{39}\right.$ TGGSTDGKQG $\left.{ }^{48}\right)$, which could be part of the active site of HM-1, as it was able to strongly inhibit the growth of the tested fungi (S. cerevisiae, Candida and Cryptococcus species). Further studies indicated the presence of a binding peptide sequence inside P6 $\left({ }^{41}\right.$ GSTDGK $\left.{ }^{46}\right)$, identifying D-44 and K-46 as essential amino acids for the killing activity. To clarify the extent to which these observations may have 
an impact on a possible therapeutic use of these peptides, further investigations must necessarily be envisaged.

A significant feature of all the previously described KTs is their interaction with/inhibition of $\beta-1,3$-glucans, which are lacking in mammalian cells, thus representing specific targets for potential antimicrobial therapy, as discussed below.

In an attempt to overcome many of the issues related to unfavorable physico-chemical features and toxicity, our group and others have exploited the idiotypic network to obtain immunological derivatives (antibodies and peptides) of some KTs capable of mimicking their antimicrobial activity.

\subsection{Production and Use of Immunological Derivatives of Killer Toxins}

The idiotypic network theory, in the case of KTs, would predict that the interaction between the functional epitope of a toxin and its specific receptor (KTR) in sensitive microbial cells should be mirrored by the binding between the idiotype (Id) of a KTneutralizing antibody $(\mathrm{Ab})$ and its anti-Id. This postulates that Id may mimic the KTR, thus acting as a vaccine, and anti-Id may mimic the active site of KT, thus acting as an antimicrobial molecule (Figure 1).

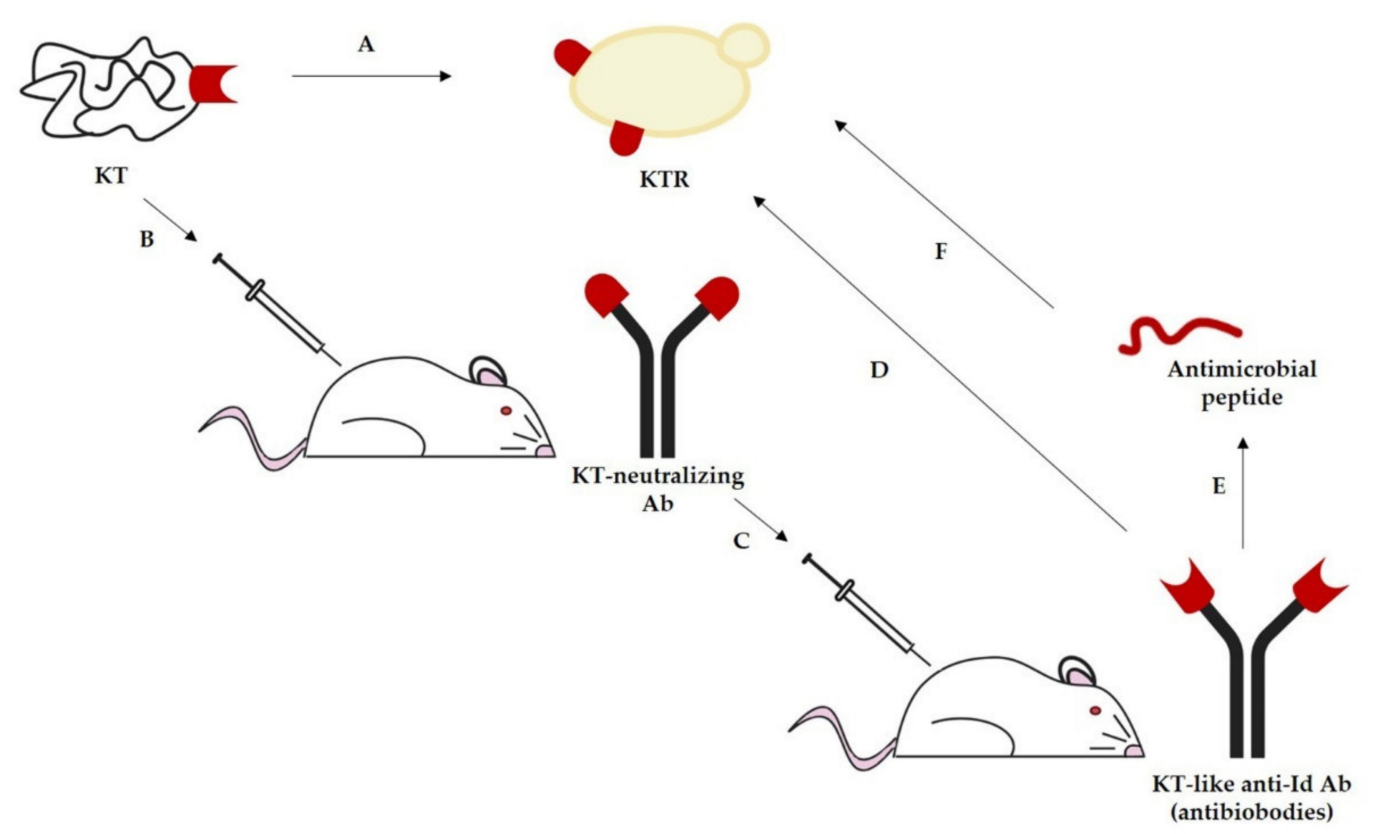

Figure 1. Application of the idiotypic network theory to the yeast killer phenomenon to obtain active immunological derivatives of KTs. (A) KT exerts a direct antimicrobial activity following interaction with the KT receptor (KTR) present on susceptible microorganisms. (B) Immunization with KT elicits neutralizing antibodies directed against the KT functional epitope. (C) The idiotype of a KTneutralizing antibody, mimicking the KTR, may act as a vaccine eliciting anti-idiotypic antibodies. (D) Anti-idiotypic antibodies, whose idiotype mimics the KT functional epitope (antibiobodies), act as antimicrobial molecules through interaction with KTR on susceptible microorganisms. (E) Peptides derived from the binding site of antibiobodies may maintain the antimicrobial activity against KT-susceptible microorganisms (F).

In this context, for many years, our research group has been studying the previously mentioned Wa96603KT produced by W. anomalus ATCC 96603 . As already highlighted, Wa96603KT was characterized by a very broad spectrum of antimicrobial activity, but it proved to be unusable as a potential therapeutic agent, except for topical use, due to its toxicity, ineffectiveness at physiological conditions and antigenicity. The goal was to obtain, through the idiotypic network, immunological derivatives of Wa96603KT still capable of exerting the antimicrobial activity of the toxin. Several studies have been carried out over 
the years, whose results are reviewed in $[37,39]$. This research has also made it possible to explore immunological aspects beyond the field of KTs, suggesting new perspectives on the anti-infective potential of Abs and their peptide derivatives, as briefly described below $[66,67]$.

It all started with the initial production of a monoclonal $\mathrm{Ab}$ (mAb KT4), capable of neutralizing Wa96603KT. Then, mAb KT4 was used as an immunogen in animals to elicit polyclonal anti-Id Abs. These anti-Id Abs, purified by affinity chromatography, were able to recognize and bind to specific KTRs on the surface of microbial cells. In yeasts, KTRs are preferentially located on germ tubes and budding scars, where $\beta$-glucans are exposed. Even more interesting was the observation that these Abs, defined as "antibiobodies" (Killer Abs, KAbs), could mimic the antimicrobial activity of Wa96603KT, thus acting as antibiotics [37]. These initial observations suggested the potential of two different experimental anti-infective approaches: Id vaccination and anti-Id therapy.

Id vaccination is based on the use of mAb KT4, or similar KT-neutralizing Abs representing the internal image of KTRs, as immunogens to elicit KAbs in vivo. Anti-Id therapy is based on the direct use of KAbs or their derivatives as therapeutics. In fact, parenteral and mucosal Id vaccination with $\mathrm{mAb}$ KT4 proved to protect animals against experimental fungal infections [37]. KAbs were also elicited following natural and experimental infections with KTR-bearing microbial cells [68], in particular following immunization with $C$. albicans cells treated with dithiothreitol and protease which expose on the surface $\beta-1,3$ D-glucans (i.e., Wa96603KT receptors) [69]. A $\beta-1,3$ D-glucan-based vaccine, consisting of laminarin, a soluble $\beta-1,3$ D-glucan, conjugated to a diphtheria toxoid, elicited the production of protective KAbs and was able to confer active and passive protection against different $\beta-1,3$ D-glucan (KTR)-bearing fungi [70,71]. Such a vaccine represents, in theory, the first example of a polyvalent, "universal" vaccine capable of protecting against infections caused by microorganisms bearing $\beta-1,3$ D-glucans on their surface.

On the other hand, the anti-Id therapy approach has been tested for a long time, leading to increasingly intriguing results. First, the production and purification of KAbs of animal or human origin made available macromolecules much more stable than KTs and therefore usable for in-depth studies of their spectrum and mechanism of action. The specificity of KAbs was demonstrated through the neutralization of their activity by $\mathrm{mAb}$ KT4. The most relevant issue concerning these KAbs was their qualitative and quantitative availability, depending on their purification from animal or human sources. To overcome this problem, KAbs were produced in monoclonal (mKAb) and recombinant (scFvKAb) formats, characterized by an absolute reproducibility. Thus, a significant activity of these KAbs was demonstrated in vitro and/or in vivo against relevant fungal, bacterial and protozoal pathogens $[37,39]$. Furthermore, the availability of the sequence of a scFvKAb allowed the production of recombinant KAbs in genetically modified human commensal bacteria, suggesting the possibility of their production in vivo following colonization [72].

The analysis of scFvKAb sequence allowed the obtaining of small peptides still able to maintain the biological activity of the whole Ab, thus functionally mimicking Wa96603KT. In particular, synthetic peptides reproducing the six complementarity determining regions (CDRs) of scFvKAb and decapeptides obtained from the sequence of ScFvKAb hypervariable region were tested in vitro against $C$. albicans, selected as a model microorganism. The highest candidacidal activity was observed with a decapeptide (P6, EKVTMTCSAS) comprising 3 amino acids of CDR1 L. Alanine scanning of P6 allowed the obtaining of a derivative peptide (killer peptide, KP, AKVTMTCSAS), characterized by an implemented anti-Candida activity [36]. The ease of obtaining KP in unlimited quantity by chemical synthesis allowed the testing of its activity in vitro and/or in vivo against numerous pathogens, both prokaryotic and eukaryotic, in different environmental conditions. KP proved to be active, with different molecular mechanisms, against diverse human pathogens, including yeasts and filamentous fungi (such as Candida, Cryptococcus and Malassezia spp., Paracoccidioides brasiliensis and Aspergillus spp.), bacteria (Gram-positive and -negative species), protozoa (such as Leishmania and Acanthamoeba spp., and Toxoplasma gondii) and viruses 
(HIV, Influenza A and Herpes simplex) [38-40]. KP also exhibited antimicrobial activity against a broad spectrum of phytopathogenic bacteria and fungi, such as Erwinia carotovora, Pseudomonas syringae, Botrytis cinerea and Fusarium oxysporum, and was expressed in planta (Nicotiana benthamiana) by using a Potato virus X (PVX)-derived vector. KP-expressing plants were much more resistant to experimental infections by phytopathogens and could be envisaged as very attractive tools for the large-scale production of peptides of interest through molecular farming [39]. In the case of microorganisms, the antimicrobial activity of KP appears to be mediated by its binding to specific receptors, consisting of $\beta$-glucans or similar polysaccharide structures, which are absent in mammalian cells. KP is further characterized by an immunomodulatory activity on cells of innate and acquired immunity that may implement its anti-infective potential [38,73]. The antimicrobial, antiviral and immunomodulatory activities of KP also rely on its ability to spontaneously and reversibly self-assemble, in a process catalyzed by $\beta-1,3$-glucans or $\beta$-glucan-like molecules, as attested by studies on structure-function relationship [38]. Moreover, the study of KP derivatives, obtained by replacing or deleting the first amino acid, demonstrated the possibility of implementing the antimicrobial activity of KP by modification of the amino acid sequence [74].

The idiotypic network approach was pursued also by Selvakumar and collaborators, through the production of recombinant anti-Id Abs representing the internal image of the previously described HM- $1 \mathrm{KT}$. ScFvHM-1 Abs were produced by recombinant DNA technology from the splenic lymphocytes of mice immunized by Id vaccination with a mAb neutralizing $(\mathrm{nmAb}) \mathrm{HM}-1$. Recombinant Abs were able to exert a broad-spectrum in vitro activity against the tested fungal strains, belonging to Saccharomyces, Candida and Cryptococcus genera, thus mimicking the antimicrobial activity of HM-1. The antifungal activity of scFvHM-1 Abs was neutralized by the HM-1 nmAb, was more potent in inhibiting the yeast growth when compared with HM-1 and was mediated, as for HM-1, by the inhibition of fungal $\beta-1,3$-glucan synthase [45-47]. Subsequently, Kabir et al. [48], based on the sequence of scFvHM- $1 \mathrm{Ab} A 1$, synthesized the peptides representing the six CDRs and other CDR-related peptides and investigated them by Dot blot, surface plasmon resonance analysis and growth inhibition assays. The antifungal activity of the CDR peptides was compared with the one of peptides derived from HM-1 KT. The most active HM-1derived peptide (P6) inhibited the growth of $S$. cerevisiae, but it was less effective against C. albicans and C. neoformans. The most active scFv-derived peptide (SP6) was effective against Candida and Cryptococcus strains through interaction with cell wall $\beta$-glucans, as demonstrated by the neutralization of anti-fungal activity with the soluble $\beta-1,3$-glucan laminarin. SP6 is a decapeptide, consisting of the first three amino acids of CDR L1 (SVS) and seven amino acids of the framework region 1, as KP. Notably, SP6 (AKVTITCSVS) and KP (AKVTMTCSAS) share 8 of the 10 amino acid residues, both present a wide spectrum of antifungal activity and probably have an identical mechanism of action.

A logical consequence of the studies on antimicrobial peptides derived from the sequence of recombinant Abs, representing the functional internal image of some KTs, was the assessment of the potential anti-infective activity of other Ab-derived peptides, synthesized as independent molecules and regardless of the specificity of the originating $\mathrm{Ab}$. Indeed, the previously described $\mathrm{Ab}$ fragments were characterized by a conserved sequence present in bovine, human, mouse and rabbit recombinant Abs deposited in data banks, with different specificities. Following these observations, numerous studies led our group to achieve interesting results on Ab-derived peptides, quickly moving away from the field of the killer phenomenon, as summarized in dedicated reviews [75,76].

\section{Conclusions}

A direct use of killer yeasts or their KTs as competitors against microbial pathogens is limited by several problems, except perhaps in the interesting option of their exploitation in vector insects for the symbiotic control of arthropod-borne diseases. KT-derived peptides or immunological derivatives of KTs, such as KT-mimicking Abs and their fragments, have 
been extensively described. KT- and Ab-derived peptides, once selected and tested, can be easily managed in terms of synthesis, quantitative production and sequence modification, in order to improve their activity and delivery systems, in view of a possible therapeutic use.

In the 21st century, infectious diseases still represent an important challenge for human health, despite the improvements in hygiene, healthcare and socioeconomic status and the extraordinary success of preventative and therapeutic approaches. Globalization and climate changes are favoring the emergence and re-emergence of new and old etiologic agents, often characterized by intrinsic or acquired resistance to anti-infective agents. The growing crowd of immunocompromised or otherwise debilitated individuals represent a further, dramatic challenge for the treatment of infectious diseases. All this severely limits the available therapeutic armamentarium, strongly highlighting the need to develop new therapeutic tools and approaches. In this scenario, KT- and Ab-derived peptides can provide leading structures for the rational design of novel, target-directed compounds applicable, by their own or in synergy with existing agents, in the field of human, animal and even plant infectious diseases.

Author Contributions: Conceptualization, L.G. and W.M.; writing—original draft preparation, T.C., T.D.S. and W.M.; writing-review and editing, L.G. and S.C. All authors have read and agreed to the published version of the manuscript.

Funding: This research received no external funding.

Institutional Review Board Statement: Not applicable.

Informed Consent Statement: Not applicable.

Conflicts of Interest: The authors declare no conflict of interest.

\section{References}

1. Cotter, P.D.; Hill, C.; Ross, R.P. Bacteriocins: Developing innate immunity for food. Nat. Rev. Microbiol. 2005, 3, 777-788. [CrossRef] [PubMed]

2. Nishie, M.; Nagao, J.; Sonomoto, K. Antibacterial peptides "bacteriocins": An overview of their diverse characteristics and applications. Biocontrol Sci. 2012, 17, 1-16. [CrossRef]

3. Cotter, P.D.; Ross, R.P.; Hill, C. Bacteriocins-A viable alternative to antibiotics? Nat. Rev. Microbiol. 2013, 11, 95-105. [CrossRef]

4. Bevan, E.A.; Makower, M. The physiological Basis of the Killer Character in Yeast. In Genetics Today: Proceedings of the XIth International Congress of Genetics, The Hague, The Netherlands, September 1963; Pergamon Press: Oxford, UK, 1963; Volume I, pp. 202-203.

5. Magliani, W.; Conti, S.; Gerloni, M.; Bertolotti, D.; Polonelli, L. Yeast killer systems. Clin. Microbiol. Rev. 1997, 10, 369-400. [CrossRef] [PubMed]

6. Klassen, R.; Schaffrath, R.; Buzzini, P.; Ganter, P.F. Antagonistic interactions and killer yeasts. In Yeasts in Natural Ecosystems: Ecology; Buzzini, P., Lachance, M.A., Yurkov, A., Eds.; Springer: Cham, Switzerland, 2017; pp. 229-275.

7. Marquina, D.; Santos, A.; Peinado, J.M. Biology of killer yeasts. Int. Microbiol. 2002, 5, 65-71. [CrossRef]

8. Golubev, W.I. Antagonistic interactions among yeasts. In Biodiversity and Ecophysiology of Yeasts. The Yeast Handbook, Péter, G., Rosa, C., Eds.; Springer: Berlin, Germany, 2006; pp. 197-219.

9. Schmitt, M.J.; Breinig, F. Yeast viral killer toxins: Lethality and self-protection. Nat. Rev. Genet. 2006, 4, 212-221. [CrossRef]

10. Liu, G.; Chi, Z.; Wang, G.; Wang, Z.-P.; Li, Y.; Chi, Z.-M. Yeast killer toxins, molecular mechanisms of their action and their applications. Crit. Rev. Biotechnol. 2013, 35, 222-234. [CrossRef]

11. Shaffrath, R.; Meinhardt, F; Klassen, R. Yeast killer toxins: Fundamentals and applications. In Physiology and Genetics. The Mycota: A Comprehensive Treatise on Fungi as Experimental Systems for Basic and Applied Research; Anke, T., Schuffler, A., Eds.; Springer: Cham, Switzerland, 2018; pp. 87-118.

12. Boynton, P.J. The ecology of killer yeasts: Interference competition in natural habitats. Yeast 2019, 36, 473-485. [CrossRef] [PubMed]

13. Mannazzu, I.; Domizio, P.; Carboni, G.; Zara, S.; Zara, G.; Comitini, F.; Budroni, M.; Ciani, M. Yeast killer toxins: From ecological significance to application. Crit. Rev. Biotechnol. 2019, 39, 603-617. [CrossRef]

14. Kurtzman, C.P.; Robnett, C.J.; Basehoar-Powers, E. Phylogenetic relationships among species of Pichia, Issatchenkia and Williopsis determined from multigene sequence analysis, and the proposal of Barnettozyma gen. nov., Lindnera gen. nov. and Wickerhamomyces gen. nov. FEMS Yeast Res. 2008, 8, 939-954. [CrossRef]

15. Kurtzman, C.P. Phylogeny of the ascomycetous yeasts and the renaming of Pichia anomala to Wickerhamomyces anomalus. Antonie Leeuwenhoek 2011, 99, 13-23. [CrossRef] 
16. Daniel, H.-M.; Redhead, S.A.; Schnürer, J.; Naumov, G.I.; Kurtzman, C.P. (2049-2050) Proposals to conserve the name Wickerhamomyces against Hansenula and to reject the name Saccharomyces sphaericus (Ascomycota: Saccharomycotina). Taxon 2012, 61, 459-461. [CrossRef]

17. May, T.W. Report of the Nomenclature Committee for Fungi-20. IMA Fungus 2017, 8, 189-203. [CrossRef] [PubMed]

18. Walker, G.M. Pichia anomala: Cell physiology and biotechnology relative to other yeasts. Antonie Leeuwenhoek 2011, 99, 25-34. [CrossRef]

19. Passoth, V.; Fredlund, E.; Druvefors, U.; Schnürer, J. Biotechnology, physiology and genetics of the yeast Pichia anomala. FEMS Yeast Res. 2006, 6, 3-13. [CrossRef] [PubMed]

20. Passoth, V.; Olstorpe, M.; Schnürer, J. Past, present and future research directions with Pichia anomala. Antonie van Leeuwenhoek 2011, 99, 121-125. [CrossRef] [PubMed]

21. Izgü, F; Altınbay, D.; Acun, T. Killer toxin of Pichia anomala NCYC 432; purification, characterization and its exo- $\beta$-1,3-glucanase activity. Enzym. Microb. Technol. 2006, 39, 669-676. [CrossRef]

22. De Ingeniis, J.; Raffaelli, N.; Ciani, M.; Mannazzu, I. Pichia anomala DBVPG 3003 Secretes a Ubiquitin-Like Protein That Has Antimicrobial Activity. Appl. Environ. Microbiol. 2009, 75, 1129-1134. [CrossRef]

23. Coda, R.; Cassone, A.; Rizzello, C.G.; Nionelli, L.; Cardinali, G.; Gobbetti, M. Antifungal Activity of Wickerhamomyces anomalus and Lactobacillus plantarum during Sourdough Fermentation: Identification of Novel Compounds and Long-Term Effect during Storage of Wheat Bread. Appl. Environ. Microbiol. 2011, 77, 3484-3492. [CrossRef]

24. Giovati, L.; Santinoli, C.; Ferrari, E.; Ciociola, T.; Martin, E.; Bandi, C.; Ricci, I.; Epis, S.; Conti, S. Candidacidal Activity of a Novel Killer Toxin from Wickerhamomyces anomalus against Fluconazole-Susceptible and -Resistant Strains. Toxins 2018, 10, 68. [CrossRef]

25. Farkas, Z.; Márki-Zay, J.; Kucsera, J.; Vágvölgyi, C.; Golubev, I.W.; Pfeiffer, I. Characterization of two different toxins of Wickerhamomyces anomalus (Pichia Anomala) VKM Y-159. Acta Biol. Hung. 2012, 63, 277-287. [CrossRef]

26. Schneider, J.; Rupp, O.; Trost, E.; Jaenicke, S.; Passoth, V.; Goesmann, A.; Tauch, A.; Brinkrolf, K. Genome sequence of Wickerhamomyces anomalus DSM 6766 reveals genetic basis of biotechnologically important antimicrobial activities. FEMS Yeast Res. 2012, 12, 382-386. [CrossRef]

27. Sawant, A.D.; Ahearn, D.G. Involvement of a cell wall receptor in the mode of action of an anti-Candida toxin of Pichia anomala. Antimicrob. Agents Chemother. 1990, 34, 1331-1335. [CrossRef] [PubMed]

28. Izgü, F.; Altınbay, D.; Türeli, A.E. In vitro activity of panomycocin, a novel exo- $\beta$-1,3-glucanase isolated from Pichia anomala NCYC 434, against dermatophytes. Mycoses 2007, 50, 31-34. [CrossRef]

29. Izgü, F.; Altınbay, D.; Türeli, A.E. In Vitro Susceptibilities of Candida spp. to Panomycocin, a Novel Exo- $\beta$-1,3-Glucanase Isolated from Pichia anomala NCYC 434. Microbiol. Immunol. 2007, 51, 797-803. [CrossRef] [PubMed]

30. Cappelli, A.; Ulissi, U.; Valzano, M.; Damiani, C.; Epis, S.; Gabrielli, M.G.; Conti, S.; Polonelli, L.; Bandi, C.; Favia, G.; et al. A Wickerhamomyces anomalus Killer Strain in the Malaria Vector Anopheles stephensi. PLoS ONE 2014, 9, e95988. [CrossRef]

31. Cappelli, A.; Valzano, M.; Cecarini, V.; Bozic, J.; Rossi, P.; Mensah, P.; Amantini, C.; Favia, G.; Ricci, I. Killer yeasts exert anti-plasmodial activities against the malaria parasite Plasmodium berghei in the vector mosquito Anopheles stephensi and in mice. Parasites Vectors 2019, 12, 329. [CrossRef] [PubMed]

32. Valzano, M.; Cecarini, V.; Cappelli, A.; Capone, A.; Bozic, J.; Cuccioloni, M.; Epis, S.; Petrelli, D.; Angeletti, M.; Eleuteri, A.M.; et al. A yeast strain associated to Anopheles mosquitoes produces a toxin able to kill malaria parasites. Malar. J. 2016, 15, 1-9. [CrossRef]

33. Cecarini, V.; Cuccioloni, M.; Bonfili, L.; Ricciutelli, M.; Valzano, M.; Cappelli, A.; Amantini, C.; Favia, G.; Eleuteri, A.M.; Angeletti, M.; et al. Identification of a Killer Toxin from Wickerhamomyces anomalus with $\beta$-Glucanase Activity. Toxins 2019, 11, 568. [CrossRef]

34. Polonelli, L.; Morace, G. Reevaluation of the yeast killer phenomenon. J. Clin. Microbiol. 1986, 24, 866-869. [CrossRef]

35. Séguy, N.; Polonelli, L.; Dei-Cas, E.; Cailliez, J.C. Effect of a killer toxin of Pichia anomala to Pneumocystis. Perspectives in the control of pneumocystosis. FEMS Immunol. Med. Microbiol. 1998, 22, 145-149. [CrossRef]

36. Polonelli, L.; Magliani, W.; Conti, S.; Bracci, L.; Lozzi, L.; Neri, P.; Adriani, D.; De Bernardis, F.; Cassone, A. Therapeutic Activity of an Engineered Synthetic Killer Antiidiotypic Antibody Fragment against Experimental Mucosal and Systemic Candidiasis. Infect. Immun. 2003, 71, 6205-6212. [CrossRef]

37. Magliani, W.; Conti, S.; Travassos, L.R.; Polonelli, L. From yeast killer toxins to antibiobodies and beyond. FEMS Microbiol. Lett. 2008, 288, 1-8. [CrossRef] [PubMed]

38. Magliani, W.; Conti, S.; Ciociola, T.; Giovati, L.; Zanello, P.P.; Pertinhez, T.; Spisni, A.; Polonelli, L. Killer peptide: A novel paradigm of antimicrobial, antiviral and immunomodulatory auto-delivering drugs. Futur. Med. Chem. 2011, 3, $1209-1231$. [CrossRef]

39. Polonelli, L.; Magliani, W.; Ciociola, T.; Giovati, L.; Conti, S. From Pichia anomala killer toxin through killer antibodies to killer peptides for a comprehensive anti-infective strategy. Antonie Leeuwenhoek 2010, 99, 35-41. [CrossRef] [PubMed]

40. Giovati, L.; Santinoli, C.; Mangia, C.; Vismarra, A.; Belletti, S.; D’Adda, T.; Fumarola, C.; Ciociola, T.; Bacci, C.; Magliani, W.; et al. Novel Activity of a Synthetic Decapeptide Against Toxoplasma gondii Tachyzoites. Front. Microbiol. 2018, 9, 753. [CrossRef]

41. Yamamoto, T.; Uchida, K.; Hiratani, T.; Miyazaki, T.; Yagiu, J.; Yamaguchi, H. In vitro activity of the killer toxin from yeast Hansenula mrakii against yeasts and molds. J. Antibiot. 1988, 41, 398-403. [CrossRef]

42. Kasahara, S.; Ben Inoue, S.; Mio, T.; Yamada, T.; Nakajima, T.; Ichishima, E.; Furuichi, Y.; Yamada, H. Involvement of cell wall $\beta$-glucan in the action of HM-1 killer toxin. FEBS Lett. 1994, 348, 27-32. [CrossRef] 
43. Takasuka, T.; Komiyama, T.; Furuichi, Y.; Watanabe, T. Cell wall synthesis specific cytocidal effect of Hansenula mrakii toxin-1 on Saccharomyces cerevisiae. Cell Mol. Biol. Res. 1995, 41, 575-581.

44. Komiyama, T.; Ohta, T.; Urakami, H.; Shiratori, Y.; Takasuka, T.; Satoh, M.; Watanabe, T.; Furuichi, Y. Pore Formation on Proliferating Yeast Saccharomyces cerevisiae Cell Buds by HM-1 Killer Toxin. J. Biochem. 1996, 119, 731-736. [CrossRef]

45. Selvakumar, D.; Karim, N.; Miyamoto, M.; Furuichi, Y.; Komiyama, T. Recombinant Single-Chain Anti-idiotypic Antibody: An Effective Fungal $\beta-1,3-G l u c a n$ Synthase Inhibitor. Biol. Pharm. Bull. 2006, 29, 1848-1853. [CrossRef] [PubMed]

46. Selvakumar, D.; Miyamoto, M.; Furuichi, Y.; Komiyama, T. Inhibition of Fungal $\beta-1,3-$ Glucan Synthase and Cell Growth by HM-1 Killer Toxin Single-Chain Anti-Idiotypic Antibodies. Antimicrob. Agents Chemother. 2006, 50, 3090-3097. [CrossRef] [PubMed]

47. Selvakumar, D.; Miyamoto, M.; Furuichi, Y.; Komiyama, T. Inhibition of $\beta$-1,3-Glucan Synthase and Cell Growth of Cryptococcus species by Recombinant Single-chain Anti-idiotypic Antibodies. J. Antibiot. 2006, 59, 73-79. [CrossRef] [PubMed]

48. Kabir, M.E.; Karim, N.; Krishnaswamy, S.; Selvakumar, D.; Miyamoto, M.; Furuichi, Y.; Komiyama, T. Peptide derived from anti-idiotypic single-chain antibody is a potent antifungal agent compared to its parent fungicide HM-1 killer toxin peptide. Appl. Microbiol. Biotechnol. 2011, 92, 1151-1160. [CrossRef]

49. Izgü, F.; Altinbay, D. Isolation and Characterization of the K5-Type Yeast Killer Protein and Its Homology with an Exo- $\beta-1,3-$ glucanase. Biosci. Biotechnol. Biochem. 2004, 68, 685-693. [CrossRef]

50. Izgü, F.; Altinbay, D.; Sertkaya, A. Enzymic Activity of the K5-Type Yeast Killer Toxin and Its Characterization. Biosci. Biotechnol. Biochem. 2005, 69, 2200-2206. [CrossRef]

51. Izgü, F.; Bayram, G.; Tosun, K.; Izgü, D. Stratum corneum lipid liposome-encapsulated panomycocin: Preparation, characterization, and the determination of antimycotic efficacy against Candida spp. isolated from patients with vulvovaginitis in an in vitro human vaginal epithelium tissue model. Int. J. Nanomed. 2017, 12, 5601-5611. [CrossRef]

52. Muhammed, M.T.; Son, D.; Izgü, F. Three dimensional structure prediction of panomycocin, a novel Exo- $\beta$-1,3-glucanase isolated from Wickerhamomyces anomalus NCYC 434 and the computational site-directed mutagenesis studies to enhance its thermal stability for therapeutic applications. Comput. Biol. Chem. 2019, 80, 270-277. [CrossRef]

53. Paris, A.P.; Persel, C.; Serafin, C.F.; Simão, R.D.C.G.; Gandra, R.F. Susceptibility of Candida albicans Isolated from Blood to Wickerhamomyces anomalous Mycocins. Curr. Microbiol. 2016, 73, 878-884. [CrossRef] [PubMed]

54. Junges, D.S.B.; Delabeneta, M.F.; Rosseto, L.R.B.; Nascimento, B.L.; Paris, A.P.; Persel, C.; Loth, E.A.; Simão, R.D.C.G.; Menolli, R.A.; Paula, C.R.; et al. Antibiotic Activity of Wickerhamomyces anomalus Mycocins on Multidrug-Resistant Acinetobacter baumannii. Microb. Ecol. 2020, 80, 278-285. [CrossRef]

55. Hatoum, R.; Labrie, S.; Fliss, I. Identification and Partial Characterization of Antilisterial Compounds Produced by Dairy Yeasts. Probiotics Antimicrob. Proteins 2013, 5, 8-17. [CrossRef]

56. Guo, F.-J.; Ma, Y.; Xu, H.-M.; Wang, X.-H.; Chi, Z.-M. A novel killer toxin produced by the marine-derived yeast Wickerhamomyces anomalus YF07b. Antonie Leeuwenhoek 2012, 103, 737-746. [CrossRef] [PubMed]

57. Tay, S.-T.; Lim, S.-L.; Tan, H.-W. Growth inhibition of Candida species by Wickerhamomyces anomalus mycocin and a lactone compound of Aureobasidium pullulans. BMC Complement. Altern. Med. 2014, 14, 439. [CrossRef] [PubMed]

58. Sundh, I.; Melin, P. Safety and regulation of yeasts used for biocontrol or biopreservation in the food or feed chain. Antonie Leeuwenhoek 2010, 99, 113-119. [CrossRef] [PubMed]

59. Muccilli, S.; Restuccia, C. Bioprotective Role of Yeasts. Microorganisms 2015, 3, 588-611. [CrossRef] [PubMed]

60. Cappelli, A.; Favia, G.; Ricci, I. Wickerhamomyces anomalus in Mosquitoes: A Promising Yeast-Based Tool for the "Symbiotic Control" of Mosquito-Borne Diseases. Front. Microbiol. 2021, 11, 621605. [CrossRef]

61. Ricci, I.; Mosca, M.; Valzano, M.; Damiani, C.; Scuppa, P.; Rossi, P.; Crotti, E.; Cappelli, A.; Ulissi, U.; Capone, A.; et al. Different mosquito species host Wickerhamomyces anomalus (Pichia anomala): Perspectives on vector-borne diseases symbiotic control. Antonie Leeuwenhoek 2011, 99, 43-50. [CrossRef]

62. Martin, E.; Bongiorno, G.; Giovati, L.; Montagna, M.; Crotti, E.; Damiani, C.; Gradoni, L.; Polonelli, L.; Ricci, I.; Favia, G.; et al. Isolation of a Wickerhamomyces anomalus yeast strain from the sandfly Phlebotomus perniciosus, displaying the killer phenotype. Med. Veter. Entomol. 2015, 30, 101-106. [CrossRef]

63. Polonelli, L.; Lorenzini, R.; De Bernardis, F.; Morace, G. Potential therapeutic effect of yeast killer toxin. Mycopathologia 1986, 96, 103-107. [CrossRef]

64. Pettoello-Mantovani, M.; Nocerino, A.; Polonelli, L.; Morace, G.; Conti, S.; di Martino, L.; de Ritis, G.; Iafusco, M.; Guandalini, S. Hansenula anomala killer toxin induces secretion and severe acute injury in the rat intestine. Gastroenterology 1995, 109, 1900-1906. [CrossRef]

65. Selvakumar, D.; Zhang, Q.-Z.; Miyamoto, M.; Furuichi, Y.; Komiyama, T. Identification and Characterization of a Neutralizing Monoclonal Antibody for the Epitope on HM-1 Killer Toxin. J. Biochem. 2006, 139, 399-406. [CrossRef] [PubMed]

66. Magliani, W.; Conti, S.; Giovati, L.; Maffei, D.L.; Polonelli, L. Anti-beta-glucan-like immunoprotective candidacidal antiidiotypic antibodies. Front. Biosci. 2008, 13, 6920-6937. [CrossRef]

67. Magliani, W.; Conti, S.; Giovati, L.; Zanello, P.P.; Sperindè, M.; Ciociola, T.; Polonelli, L. Antibody Peptide Based Antifungal Immunotherapy. Front. Microbiol. 2012, 3, 190. [CrossRef]

68. Polonelli, L.; De Bernadis, F.; Conti, S.; Boccanera, M.; Magliani, W.; Gerloni, M.; Cantelli, C.; Cassone, A. Human natural yeast killer toxin-like candidacidal antibodies. J. Immunol. 1996, 156, 1880-1885. 
69. Bromuro, C.; Torosantucci, A.; Chiani, P.; Conti, S.; Polonelli, L.; Cassone, A. Interplay between protective and inhibitory antibodies dictates the outcome of experimentally disseminated Candidiasis in recipients of a Candida albicans vaccine. Infect. Immun. 2002, 70, 5462-5470. [CrossRef] [PubMed]

70. Torosantucci, A.; Bromuro, C.; Chiani, P.; De Bernardis, F.; Berti, F.; Galli, C.; Norelli, F.; Bellucci, C.; Polonelli, L.; Costantino, P.; et al. A novel glyco-conjugate vaccine against fungal pathogens. J. Exp. Med. 2005, 202, 597-606. [CrossRef] [PubMed]

71. Rachini, A.; Pietrella, D.; Lupo, P.; Torosantucci, A.; Chiani, P.; Bromuro, C.; Proietti, C.; Bistoni, F.; Cassone, A.; Vecchiarelli, A. An anti-beta-glucan monoclonal antibody inhibits growth and capsule formation of Cryptococcus neoformans in vitro and exerts therapeutic, anticryptococcal activity in vivo. Infect. Immun. 2007, 75, 5085-5094. [CrossRef]

72. Beninati, C.; Oggioni, M.R.; Boccanera, M.; Spinosa, M.R.; Maggi, T.; Conti, S.; Magliani, W.; De Bernardis, F.; Teti, G.; Cassone, A.; et al. Therapy of mucosal candidiasis by expression of an anti-idiotype in human commensal bacteria. Nat. Biotechnol. 2000, 18, 1060-1064. [CrossRef] [PubMed]

73. Ferrari, L.; Martelli, P.; Saleri, R.; De Angelis, E.; Ferrarini, G.; Cavalli, V.; Passeri, B.; Bazzoli, G.; Ogno, G.; Magliani, W.; et al. An engineered anti-idiotypic antibody-derived killer peptide (KP) early activates swine inflammatory monocytes, CD3+CD16+ natural killer T cells and CD4+CD8 $\alpha+$ double positive CD $8 \beta+$ cytotoxic T lymphocytes associated with TNF- $\alpha$ and IFN- $\gamma$ secretion. Comp. Immunol. Microbiol. Infect. Dis. 2020, 72, 101523. [CrossRef]

74. Ciociola, T.; Pertinhez, T.A.; De Simone, T.; Magliani, W.; Ferrari, E.; Belletti, S.; D’Adda, T.; Conti, S.; Giovati, L. In vitro and in vivo anti-Candida activity and structural analysis of killer peptide (KP)-derivatives. J. Fungi 2021, 7, 129. [CrossRef]

75. Magliani, W.; Giovati, L.; Ciociola, T.; Sperindè, M.; Santinoli, C.; Conti, G.; Conti, S.; Polonelli, L. Antibodies as a source of anti-infective peptides: An update. Future Microbiol. 2015, 10, 1163-1175. [CrossRef] [PubMed]

76. Ciociola, T.; Giovati, L.; Conti, S.; Magliani, W. Anti-Infective Antibody-Derived Peptides Active against Endogenous and Exogenous Fungi. Microorganisms 2021, 9, 143. [CrossRef] [PubMed] 